\title{
Atmospheric particle formation events at Värriö measurement station in Finnish Lapland 1998-2002
}

\author{
H. Vehkamäki ${ }^{1}$, M. Dal Maso ${ }^{1}$, T. Hussein ${ }^{1}$, R. Flanagan ${ }^{1,4}$, A. Hyvärinen ${ }^{2}$, J. Lauros ${ }^{1}$, J. Merikanto ${ }^{1}$, \\ P. Mönkkönen ${ }^{1}$, M. Pihlatie ${ }^{1}$, K. Salminen ${ }^{2}$, L. Sogacheva ${ }^{1}$, T. Thum ${ }^{2}$, T. M. Ruuskanen ${ }^{1}$, P. Keronen ${ }^{1}$, P. P. Aalto ${ }^{1}$, \\ P. Hari ${ }^{3}$, K. E. J. Lehtinen ${ }^{1}$, Ü. Rannik ${ }^{1}$, and M. Kulmala ${ }^{1}$ \\ ${ }^{1}$ Department of Physical Sciences, P.O. Box 64, 00014 University of Helsinki, Finland \\ ${ }^{2}$ Finnish Meteorological Institute, P.O Box 503, 00101 Helsinki, Finland \\ ${ }^{3}$ Department of Forest Ecology, P.O. Box 27, 00014 University of Helsinki, Finland \\ ${ }^{4}$ Dep. of Experimental Physics and Environmental Change Institute, National Univ. of Ireland, Galway, University Road, \\ Galway, Ireland
}

Received: 13 May 2004 - Published in Atmos. Chem. Phys. Discuss.: 25 June 2004

Revised: 1 October 2004 - Accepted: 3 October 2004 - Published: 5 October 2004

\begin{abstract}
During the calendar years 1998-2002, 147 clear $8 \mathrm{~nm}$ diameter particle formation events have been identified at the SMEAR I station in Värriö, northern Finland. The events have been classified in detail according to the particle formation rate, growth rate, event starting time, different trace gas concentrations and pre-existing particle concentrations as well as various meteorological conditions. The frequency of particle formation and growth events was highest during the spring months between March and May, suggesting that increasing biological activity might produce the precursor gases for particle formation. The apparent $8 \mathrm{~nm}$ particle formation rates were around $0.1 / \mathrm{cm}^{3} \mathrm{~s}$, and they were uncorrelated with growth rates that varied between 0.5 and $10 \mathrm{~nm} / \mathrm{h}$. The air masses with clearly elevated sulphur dioxide concentrations (above $1.6 \mathrm{ppb}$ ) came, as expected, from the direction of the Nikel and Monschegorsk smelters. Only 15 formation events can be explained by the pollution plume from these sources.
\end{abstract}

\section{Introduction}

Atmospheric particles affect the earth's climate both directly by scattering incoming solar radiation and also the long wave radiation escaping from our planet, and indirectly by influencing the properties and occurrence of clouds (Menonet al., 2002; Stott et al., 2000). Particles can also have undesirable effects on human health (Dockery and Pope, 1994; Stieb et al., 2002). Most of the atmospheric particulate matter is formed by condensation of vapours onto pre-existing particles. The smallest particles are either formed entirely from vapour without any condensation seed nuclei (Kulmala,

Correspondence to: $\mathrm{H}$. Vehkamäki

(hanna.vehkamaki@helsinki.fi)
2003), or by electrostatically enhanced condensation onto atmospheric ions (Yu and Turco, 2000).

Atmospheric fine particle formation events have been observed around the world in various environments from polluted cities to remote polar background areas (Kulmala et al., 2004). The vapours which nucleate to form particles have not yet been identified, but sulphuric acid together with ammonia are considered to be the prime candidates (Napari et al., 2002). It is quite likely that different mechanisms dominate particle formation in different atmospheric conditions. Using current aerosol instrumentation we can detect the newly formed particles only when they have grown to diameters above the experimental cut-off of 3-10 nm. Therefore, it has been suggested that particle nucleation occurs continuously, but the formation events are only observed when initial growth is enabled (Kulmala et al., 2000).

This work presents the analysis of continuous aerosol particle size distribution data collected during the five year period 1998-2002 at the SMEAR I station in Värriö $250 \mathrm{~km}$ north of the Arctic Circle in Finnish Lapland. Most of the time the air at the station is pollution free with no local sources, but occasionally very polluted air reaches Värriö from the Nikel and Montschegorsk smelters less than $200 \mathrm{~km}$ north and east of the station, respectively. The focus of the analysis was to identify the particle formation events, compare the event and non-event days and study the influence of meteorological variables, air mass origin and measured trace gas concentrations on the particle formation.

\section{Measurement station}

The Värriö measurement station SMEAR I (Hari et al., 1994) is located at $67^{\circ} 46^{\prime} \mathrm{N}$ latitude and $29^{\circ} 35^{\prime} \mathrm{E}$ longitude $250 \mathrm{~km}$ north of the Arctic circle in Eastern Lapland, less than ten 
Table 1. The criteria for formation and growth event classification.

\begin{tabular}{|c|c|}
\hline Class & Criteria \\
\hline 1 & Clear formation, smooth growth \\
\hline 2 & Clear formation but fluctuating or distorted growth \\
\hline 3 & $\begin{array}{l}\text { Unclear formation (Number of particles with diameter } \\
\text { less than } 15 \mathrm{~nm} \text { increases) }\end{array}$ \\
\hline 0 & Possible formation \\
\hline $\mathrm{X}$ & Clear growth starting above the smallest size classes \\
\hline $\mathrm{P}$ & $\begin{array}{l}\text { Pollution during formation }\left(\mathrm{SO}_{2} \text { concentration }\right. \\
\text { above } 0.35 \mathrm{ppb})\end{array}$ \\
\hline
\end{tabular}

kilometres from the Finnish-Russian border. The measurements were performed on the top of a hill $390 \mathrm{~m}$ above sea level (asl). The main tree species was about 50 year-old Scots pine (Pinus Sylvestris L.) with a mean height of approximately eight meters and a mean diameter of approximately eight centimetres. The station is located below the alpine timberline ( $400 \mathrm{asl}$ ), and some of the fjell tops are above it. The nearest small road is $8 \mathrm{~km}$ from the station, and the nearest major road $100 \mathrm{~km}$. There are no towns or industry close by and thus practically no local pollution. The nearest major pollution sources were Montschegorsk located $150 \mathrm{~km}$ east and Nikel located $190 \mathrm{~km}$ north of the station. The Värriö station and Monschegorsk are separated by a line of mountains ranging from north to south on the Russian side of the border.

The aerosol particle size distributions were measured with a DMPS system (Aalto et al., 2001; Jokinen and Mäkelä, 1997) consisting of a Hauke-type DMA (length $28 \mathrm{~cm}$ ) and a TSI 3010 condensation nucleus counter. The lower and upper cut-off diameters of the system are $8 \mathrm{~nm}$ and $500 \mathrm{~nm}$, respectively, and the set up measured one full size distribution every $10 \mathrm{~min}$, giving 144 distributions a day. The inlet for the DMPS system was at a height of $2 \mathrm{~m}$ on the wall of the measurement cabin, and the DMPS itself was inside the cabin at room temperature, which at low atmospheric temperatures led to evaporation of water and possibly some other volatile compounds from the particles before they entered the instrument.

The measurements for trace gases (sulphur dioxide $\mathrm{SO}_{2}$, ozone $\mathrm{O}_{3}$, nitrogen oxides $\mathrm{NO}_{\mathrm{x}}$ ) temperature, absolute humidity and wind speed were also performed continuously at $2.2 \mathrm{~m}, 4.4 \mathrm{~m}$ (no trace gases), $6.6 \mathrm{~m}, 9 \mathrm{~m}$ and $15 \mathrm{~m}$ levels of the measurement tower adjacent to the cabin. $\mathrm{SO}_{2}$ was measured with a fluorescence analyser (Model 43S, Thermo Environmental Instruments, Inc., detection limit $0.1 \mathrm{ppb}$, maximum error $+/-0.05 \mathrm{ppb}$ ). A detailed description of the other trace gas measurements can be found in Ruuskanen et al. (2003). UVA, UVB, photosynthetically active, reflected and global radiation and wind direction were measured at the top of the tower $(15 \mathrm{~m})$, and relative humidity and pres-
Table 2. Number of formation events during calendar years 19982002.

\begin{tabular}{ll}
\hline Year & Number of events classes 1 and 2 \\
\hline 1998 & 32 \\
1999 & 30 \\
2000 & 26 \\
2001 & 27 \\
2002 & 32 \\
$1998-2002$ & 147 \\
\hline
\end{tabular}

sure at $2 \mathrm{~m}$ height. Rainfall was also measured and we had access to the snow depth data of the Finnish Environment Institute. To determine the origin of the air masses we calculated back trajectories using the NOAA Air Resources Laboratory HYSPLIT model.

\section{Formation event characterization}

The particle size distribution evolution was analysed on each day during 1998-2002, and the particle formation events were identified and characterized. Table 1 shows the criteria used when classifying the formation events. Non-event days are the days that do not fall into any of the categories in Table 1. The analysis focuses on class one and two events, the number of which during each calendar year is given in Table 2.

The frequency of the formation events exhibits a clear spring maximum with just over 0.2 events per day in May, as can been seen in Fig. 1. The spring maximum is also typical for other Boreal sites like the SMEAR II station in Hyytiälä, southern Finland (Mäkelä et al., 1997). However, there it occurs in April with around 0.4 events per day, which is consistent with the fact that spring starts earlier in a more southern location. The weaker autumn maximum in the particle formation event frequency that is observed in Hyytiälä (0.15 events per day in September) can be seen in Värriö in August (above 0.1 events per day), but it is not as clearly distinguishable. Throughout summer and autumn the number of events per day in Värriö is below 0.1, decreasing to only less than 0.03 events per day during the winter months. In Hyytiälä the event frequencies are somewhat higher, close to 0.1 in the summer and around 0.05 events per day during the winter. Urban St. Louis (Shi, 2003) exhibits a more scattered picture with a minimum of around 0.05 events per day during midwinter, and the highest values above 0.3 events per day during April, July and September. In contrast to the other sites, Hohenpeissenberg (Birmili et al., 2003) in rural central Europe exhibits the maximum with over 0.25 events occurring during midwinter, and minimum (around 0.075 events per day), during late summer and early autumn. It seems that 


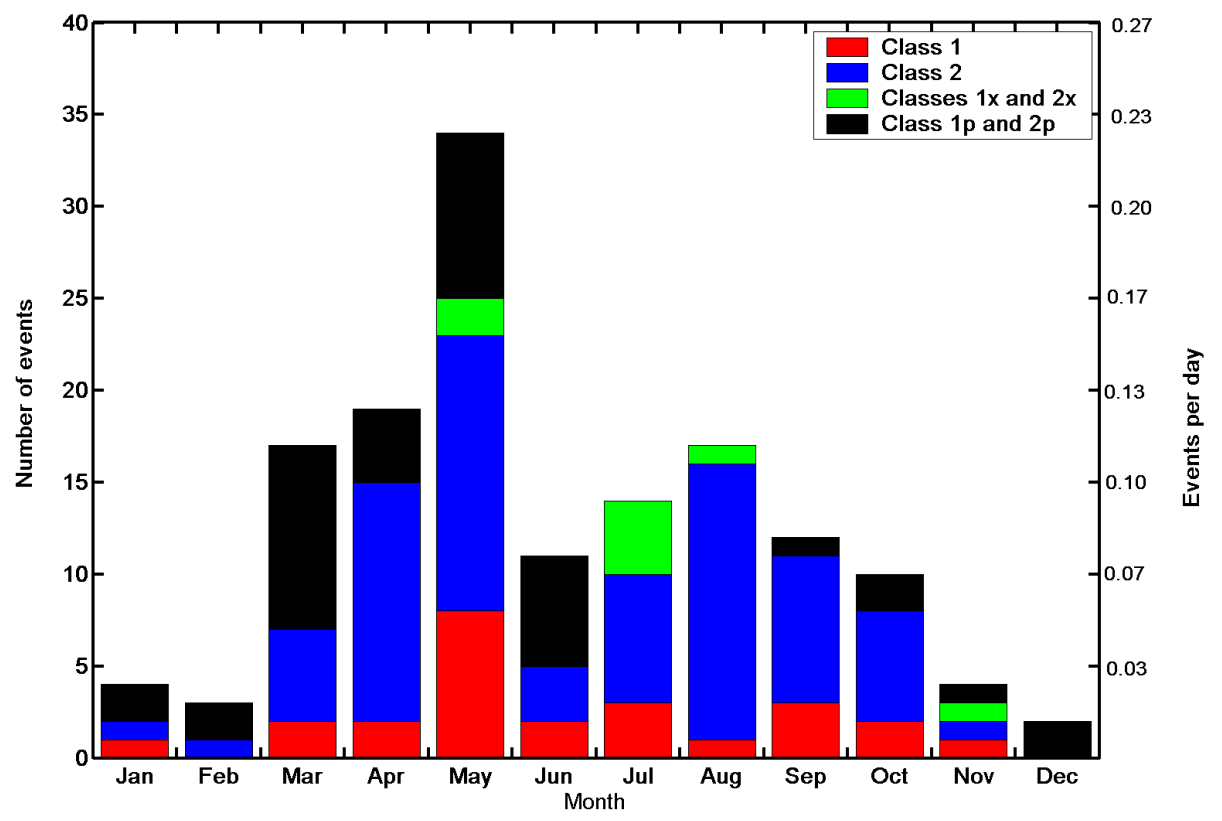

Fig. 1. The monthly distribution of particle formation events 1998-2002. The left hand vertical axis shows the frequency of events per day.

very different processes are controlling the particle formation events at these different locations, but there are clear similarities between the two boreal sites of Hyytiälä and Värriö.

The majority of particle formation events observed all around the world (Kulmala et al., 2004) start between sunrise and noon. However, there is one exception: Wiedensohler et al. (1997) observed particle formation events during night time. Figure 2 shows the yearly cycle of event starting times in Värriö together with sunrise and sunset times. The starting time is the time when elevated concentrations of $8 \mathrm{~nm}$ particles were first observed. In Värriö most of the events also occurred during the daytime, suggesting that photochemistry is involved. Sunlight is most likely needed to produce the nucleating and condensing vapours from their precursors by photochemical reactions, but boundary layer mixing following solar heating can be another factor connecting solar radiation with formation bursts. In Värriö the formation event starting times were rather constant throughout the year, unlike in Hyytiälä where they clearly follow the sunrise curve. It must be kept in mind that in Hyytiälä, instrumentation is available with a $3 \mathrm{~nm}$ diameter cut-off. The cut-off in Värriö was $8 \mathrm{~nm}$ and thus the time difference between nucleation and observation could be much larger in Värriö, depending on growth rate. This difference in instrumentation might be the reason we a see a difference in the behaviour of event starting times at the two stations.

Due to their rarity, dark time formation events deserve some special attention. Most of the formation events, which occurred when the sun was below the horizon started within a few hours after sunset, which could be explained by actual formation during daylight and slow growth to $8 \mathrm{~nm}$ diameter.
Some of the dark time events occurred after a clear event on the previous day was interrupted by rain and the particle production and growth resumed when the rain stopped. Somewhat surprisingly there were some formation events also during the midwinter polar night. The other possible explanation for dark time events is that the formation and growth had occurred even days previous at lower latitudes (where there was still some sunlight), since the growth rate in the Arctic and marine atmosphere can sometimes be very small, even as low as $0.1-0.5 \mathrm{~nm} / \mathrm{h}$ (see Kulmala et al., 2004).

Formation events were observed to cluster together, which was most likely due to periods of weather conditions that favour particle formation. However, two class 1 events very rarely occur on two consecutive days, which can be explained by the fact that a strong particle formation event will increase the condensation sink and thus decrease the concentration of condensable vapours. There were 10 cases where two events occurred during the same calendar day, the minimum difference in starting times was 6 hours, and the events were typically of class 2 or 3 . The frequency of such days exhibited no seasonal variation.

We also studied the effect of snow fall and melting on the occurrence of formation events, but did not find any correlation beyond the fact that sunny days in the spring time resulted both in snow melting and particle formation, and events extremely rarely occurred on days with snowfall.

\section{Relation to air mass origin and wind conditions}

Figure 3 shows a characterization of the formation events according to starting time and air mass origin. Morning events 


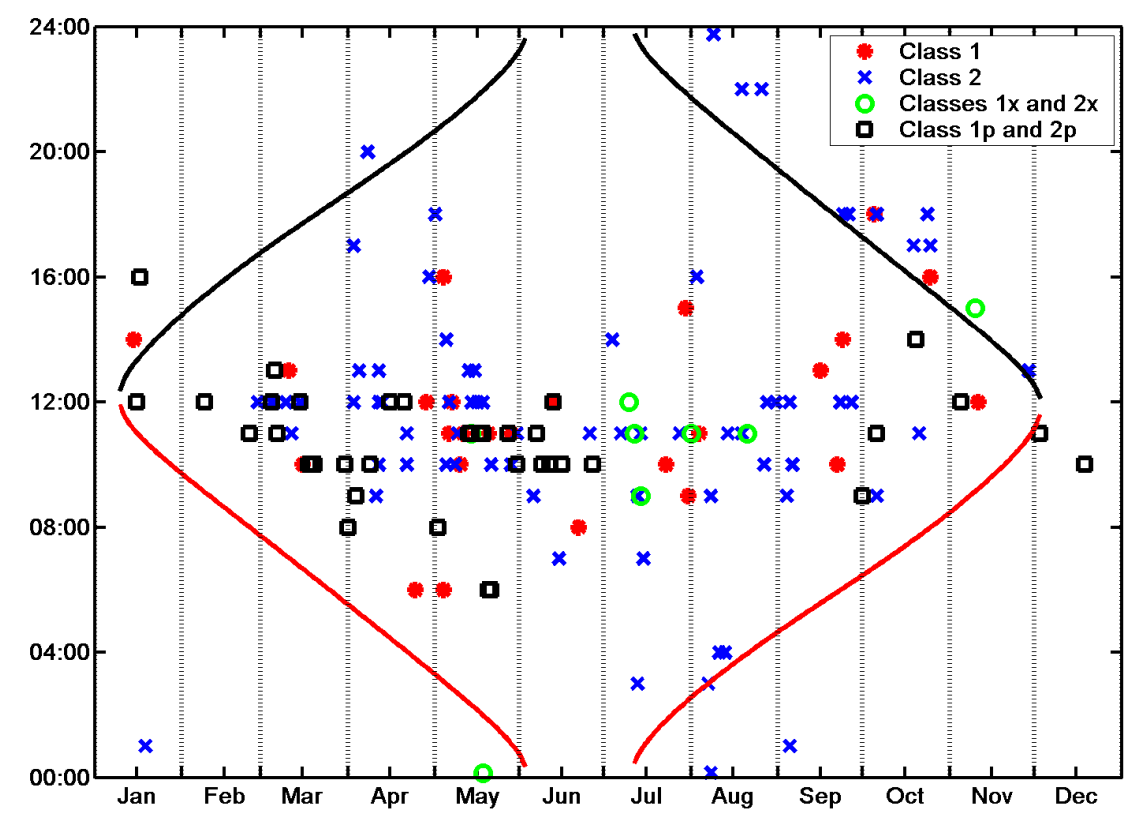

Fig. 2. Daily variation of starting times of formation events in Värriö 1998-2002. The sunrise and sunset times are marked with red and black solid lines, respectively.

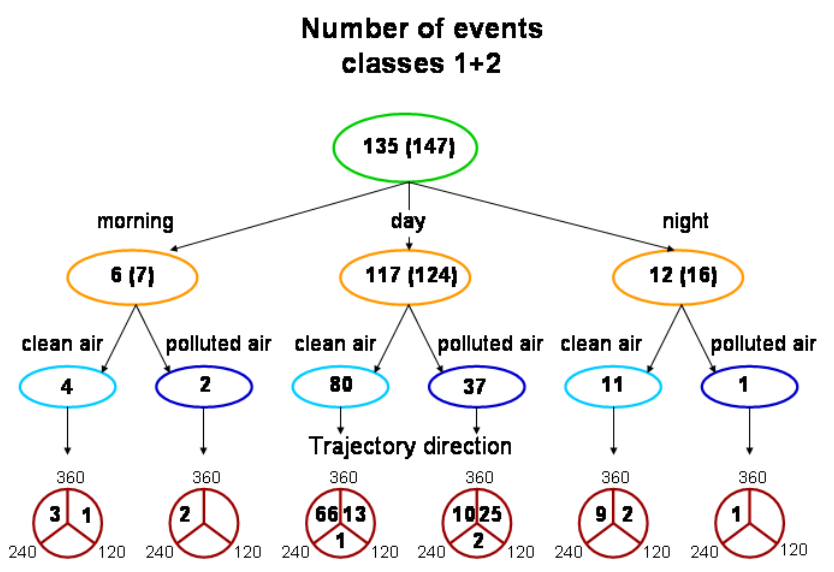

Fig. 3. Characterization of formation events by starting time and air mass. Morning stands for the time between midnight and sunrise, evening the time after sunset but before midnight. The air mass was considered polluted if the average concentration of $\mathrm{SO}_{2}$ was over $0.35 \mathrm{ppb}$ during the ten hour period surrounding the event starting time. The numbers shown in parentheses are the total number of events including those with no sulphur dioxide data.

start between midnight and sunrise, and evening events between sunset and midnight. The air mass was considered polluted if the average concentration of $\mathrm{SO}_{2}$ (at $2.2 \mathrm{~m}$ level) was over $0.35 \mathrm{ppb}\left(1 \mu \mathrm{g} / \mathrm{m}^{3}\right)$ during the ten hour period surrounding the event starting time. The diagram in Fig. 3 indicates that most of the polluted air came from the direction of the Kola Peninsula's copper and nickel smelteries at
Montchegorsk and Nikel (Ruuskanen et al., 2003). In two cases (dates 20. and 21.5.1999) the $\mathrm{SO}_{2}$ concentrations were rather high $(2.6-4.2 \mathrm{ppb})$ and the trajectories came from sector $240^{\circ}-360^{\circ}$, but the local wind was clearly easterly. These cases were placed in the sector $0^{\circ}-120^{\circ}$. In the remaining polluted cases with trajectories from sectors $120^{\circ}-240^{\circ}$ and $240^{\circ}-360^{\circ}$ the $\mathrm{SO}_{2}$ concentrations were around $0.5 \mathrm{ppb}$, and, in only a couple of cases above $1 \mathrm{ppb}$, with a maximum of $1.6 \mathrm{ppb}$. Figure 4 shows the distribution of formation events according to the $\mathrm{SO}_{2}$ concentration. The highest $10 \mathrm{~h}$ average concentration on an event day was $65 \mathrm{ppb}$.

Pirjola et al. (1998) showed that the measured $\mathrm{SO}_{2}$ concentrations can only explain part of the formation events occurring in Värriö, typically the ones where the air mass comes from the Kola peninsula. Most of the morning and evening time events occurred in $\mathrm{SO}_{2}$ clean conditions with trajectories from west or north-west, therefore the Kola pollution sources do not explain the dark time events. One possibility is that these trajectories brought aged polluted air from North America or Britain, and the particle formation was caused by an unknown vapour which could not be detected with the current instruments in Värriö.

Table 3 shows the local wind direction distribution on formation event and non-event days. The west-south-westerly winds were connected with events and the south-westsoutherly winds with non-events. Westerly winds and trajectories from the Atlantic ocean support the suggestion that air masses and synoptic weather conditions affect particle formation (Nilsson et al., 2001). 


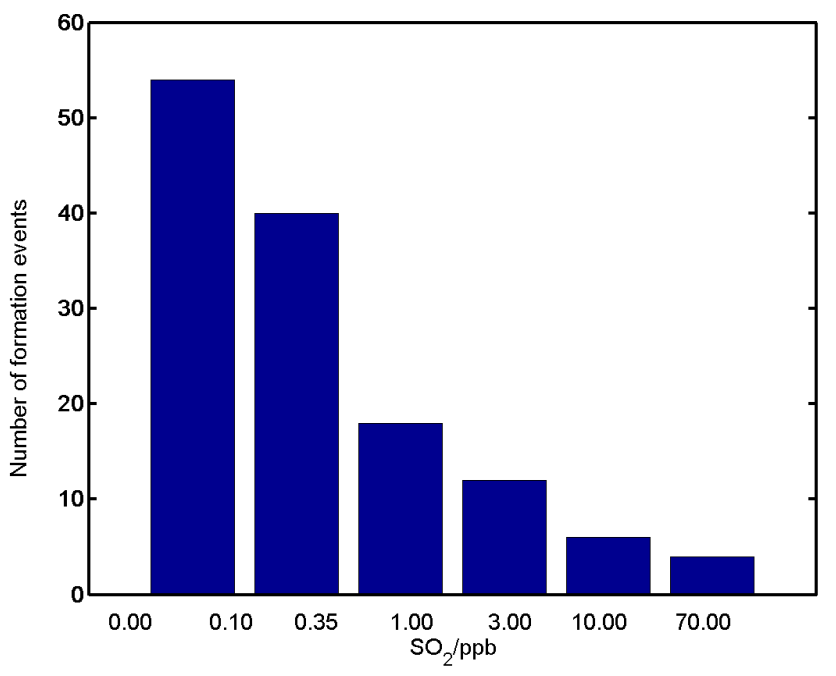

Fig. 4. Distribution of days according to the $\mathrm{SO}_{2}$ concentration. The concentration is divided into bins $0-0.1 \mathrm{ppb}, 0.1-0.35 \mathrm{ppb}$, $0.35-1 \mathrm{ppb}, 1-3 \mathrm{ppb}, 3-10 \mathrm{ppb}$ and 10-70 ppb.

Table 3. Comparison of local wind direction distribution over 1998-2002 non-event and event days.

\begin{tabular}{ccc}
\hline & event & non-event \\
\hline degrees & $\%$ & $\%$ \\
$0-45$ & 12 & 10 \\
$45-90$ & 19 & 19 \\
$90-135$ & 7 & 10 \\
$135-180$ & 3 & 9 \\
$180-225$ & 12 & 23 \\
$225-270$ & 32 & 22 \\
$270-315$ & 8 & 4 \\
$315-360$ & 8 & 4 \\
\hline
\end{tabular}

\section{Effect of temperature, trace gas concentrations and solar radiation on particle formation}

The yearly averages of the diurnal behaviour of meteorological quantities and trace gas concentrations were compared on event days and non-event days. We also made the comparison separately for different seasons to check if the differences between event and non-event conditions are dependent on the time of year. For trace gases and temperature we used the value measured at $2.2 \mathrm{~m}$ and for relative humidity the value measured at $2 \mathrm{~m}$ height, which was close to the particle measurement level.

The temperature, on average, was higher on event days than non-event days. This naturally reflects the fact that most of the events occurred during the relatively warm season. The seasonal comparisons show that during winter the event days have higher temperatures than non-event days,

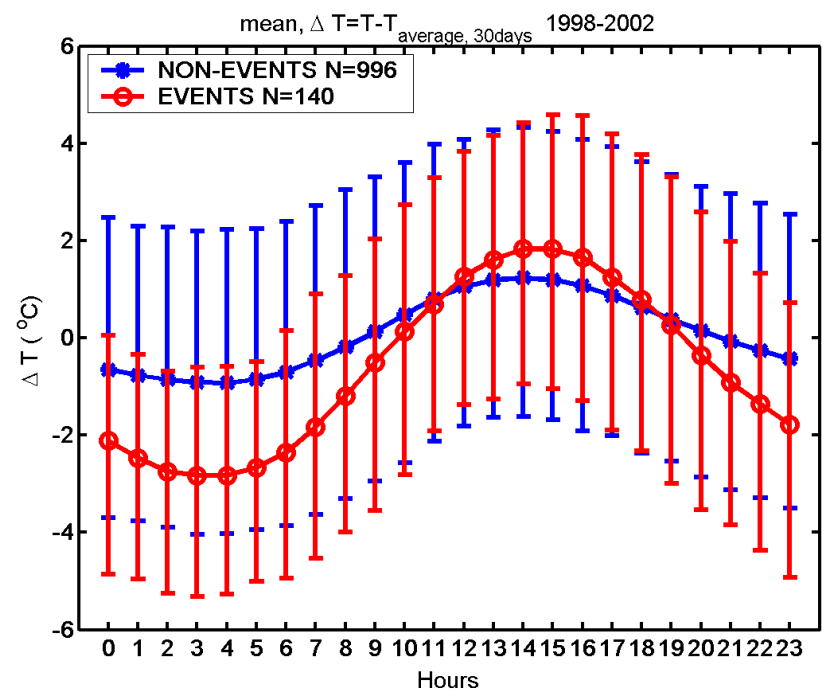

Fig. 5. Mean temperature difference compared to the seasonal (sliding 30 day average) temperature on event and non-event days with standard deviations. The legend also shows the number of event and non-event days with reliable data for temperature.

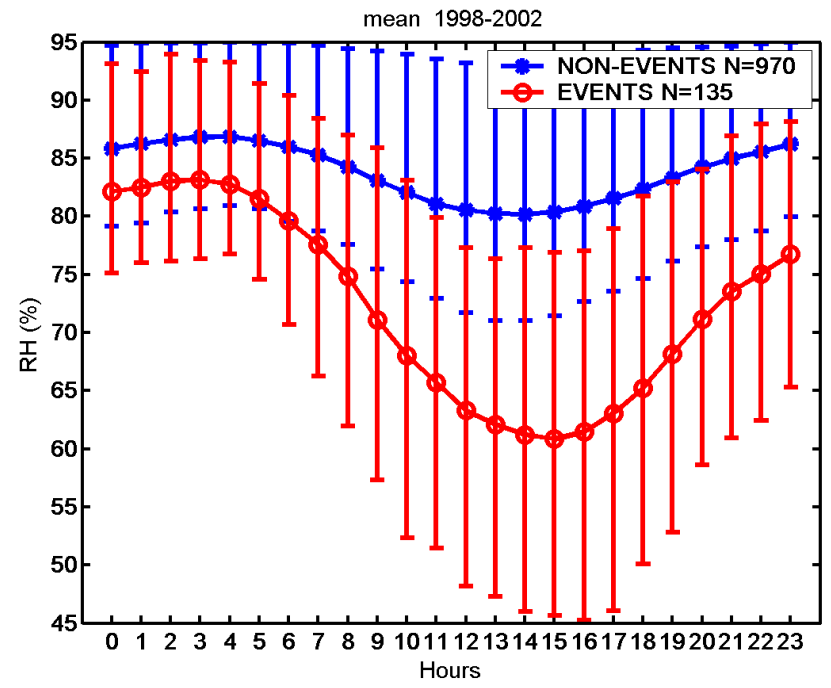

Fig. 6. Mean diurnal behaviour of relative humidity on event and non-event days over the whole period 1998-2002. The legend shows the number of days with reliable relative humidity measurement data. Standard deviations are also shown.

and during the rest of the year the event days are on average colder than the non-event days. To eliminate the effect of seasonal variations, we show in Fig. 5 the temperature difference compared to 30 day sliding mean temperatures. This figure illustrates that event days have lower morning temperatures but higher noon temperatures which is typical for clear sky conditions. Low temperatures can strongly enhance particle formation since the saturation vapour pressures of atmospheric substances decrease exponentially with decreasing temperature. 

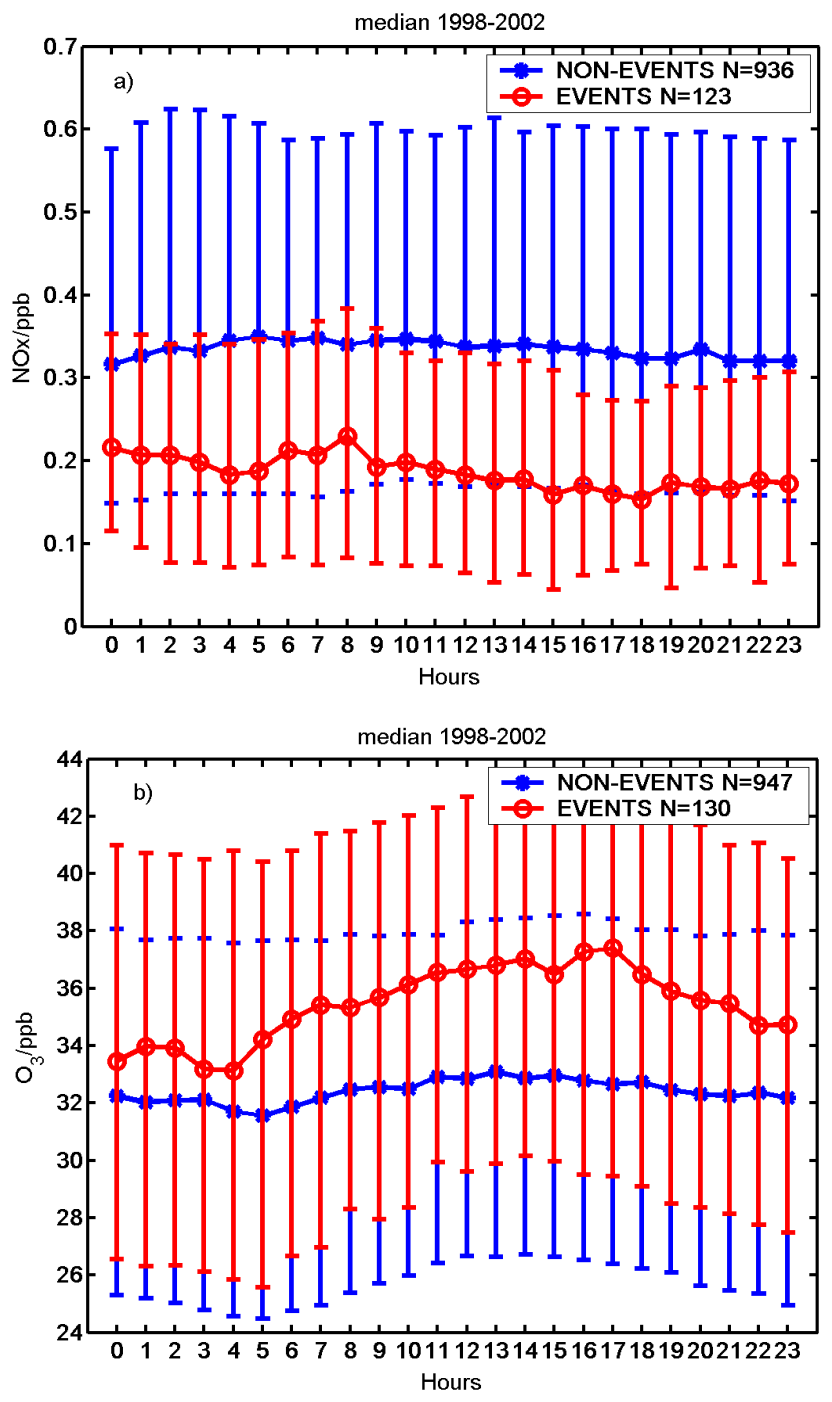

Fig. 7. Median concentrations of (a) $\mathrm{NO}_{\mathrm{x}}$ and (b) $\mathrm{O}_{3}$ during event and non-event days. The legend shows the number of days with reliable measurement data. $25 \%$ and $75 \%$ percentiles are also shown.

The relative humidity was lower during event days, except for the winter months, when no clear difference was observed. Figure 6 shows the mean diurnal behaviour of relative humidity on event and non-event days. Eliminating the seasonal variations in the same way as with temperature (Fig. 5) did not make a significant difference to this figure. High water vapour concentration in the air was anticorrelated with particle formation, as has also been observed in Hyytiälä (Boy and Kulmala, 2002). This could be explained by the fact that relative humidity is higher in cloudy days with less solar radiation to produce $\mathrm{OH}$ radicals and further condensable vapours and/or the high humidity causes the pre-existing aerosol sizes to grow so that more surface area is available for vapour condensation.

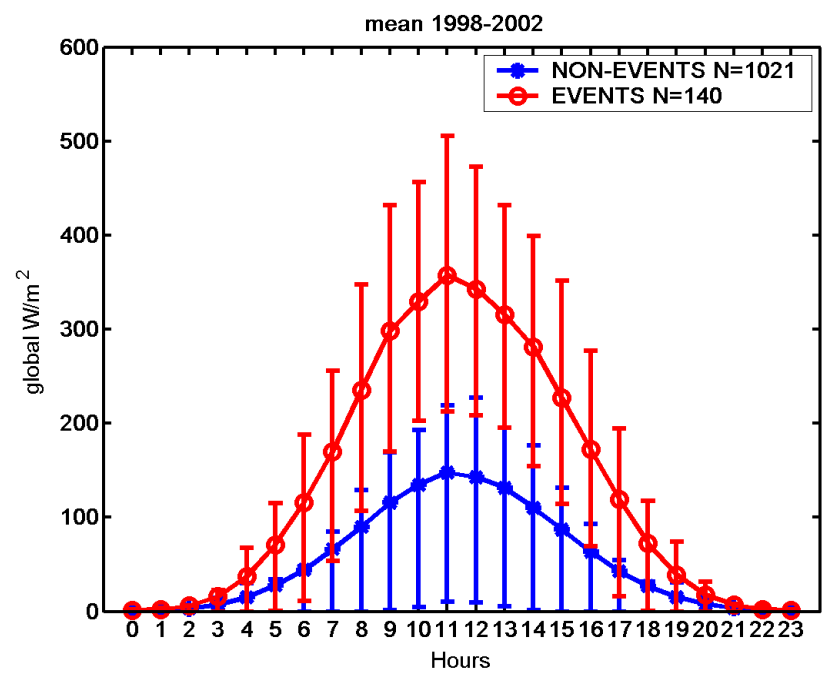

Fig. 8. Mean global radiation over all seasons for event and nonevent days. The legend shows the number of days with reliable measurement data. Standard deviations are also shown.

The concentration of $\mathrm{NO}_{\mathrm{x}}$ was clearly lower and the concentration of $\mathrm{O}_{3}$ higher on event days for the whole year as shown in Figs. 7a and b. Again, removing the seasonal trend did not change these pictures significantly. The median NO concentration did not differ on event and non-event days. Due to the measurement set-up, the $\mathrm{NO}_{\mathrm{x}}$ concentrations used in this paper may from time to time include considerable amounts of other nitrogen containing species than $\mathrm{NO}$ and $\mathrm{NO}_{2}$.

Global radiation was higher on event days during all seasons except winter, when there was very little difference between event and non-event days. The mean diurnal behaviour comparison is shown in Fig. 8.

The higher ozone concentration during event days compared with non-event days can be explained by photochemical reaction cycles (Seinfeld and Pandis, 1998). The same mechanism would explain the lower $\mathrm{NO}_{\mathrm{x}}$ concentrations on event days.

\section{Formation and growth rates}

Formation and growth rates of $8 \mathrm{~nm}$ particles were estimated from the size distribution data using the methods presented by Mäkelä et al. (2000) and Kulmala et al. (2001). The particle growth rates varied between 0.5 and $10 \mathrm{~nm} / \mathrm{h}$ (Fig. 9a). The growth rates have a maximum in summertime and minimum in wintertime. The formation and growth rates in December, January and February are left out since there are only a few data points for these months. Growth rates in Hyytiälä, Hohenpeissenberg and St. Louis also have a summer maximum and winter minimum, and even their values are very similar (Kulmala et al., 2004). 


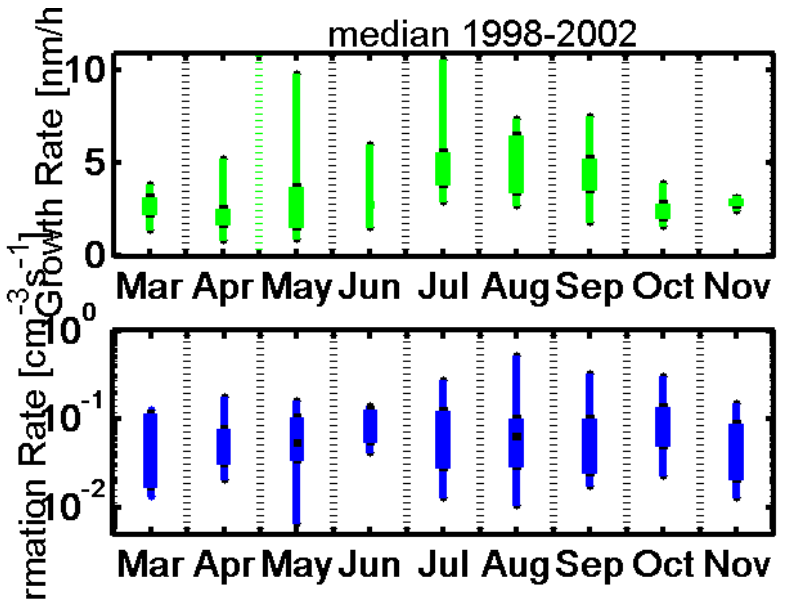

Fig. 9. Seasonal variations of growth rate (a) and formation rate (b). Median, maximum, minimum, $25 \%$ and $75 \%$ percentiles are shown for each month. December, January and February are left out due to poor statistics.

The formation rates were around $0.1 \mathrm{~cm}^{-3} \mathrm{~s}^{-1}$ (Fig. 9b), and they exhibited no clear seasonal variation. These formation rates are lower than those typical in Hyytiälä (0.5$1 \mathrm{~cm}^{-3} \mathrm{~s}^{-1}$ ), and more anthropogenically affected measurement sites like Hohenpeissenberg and St. Louis. Furthermore, the growth rates and the formation rates did not seem to correlate with each other. This finding supports the conclusion of several other studies (see Kulmala et al., 2004). Figures 10 and 11 show the mean, minimum and maximum growth and formation rates, respectively, for formation events occurring at different times of the day and in different air masses (characterization as in Fig. 3). The growth rates were highest in the morning time clean air events when the air masses came from a westerly direction. For day and evening events, easterly air masses led to the highest growth rates. Polluted air with high $\mathrm{SO}_{2}$ concentrations did not increase the growth rates significantly. Note that as can be seen from Fig. 3, during morning and night there was altogether only three polluted events and in all those cases the $\mathrm{SO}_{2}$ concentration was only around $0.5 \mathrm{ppb}$. Morning events had, on average, slightly lower formation rates than the day and night events. In the case of $\mathrm{SO}_{2}$ clean air masses, easterly trajectories led to higher formation rates, for polluted day events southerly air masses had clearly lower formation rates.

Figure 12 shows the condensation sink (Dal Maso et al., 2002; Kulmala et al., 2001) calculated from the measured aerosol size distributions during different kinds of event conditions. The condensation sink describes the ability of the pre-existing aerosol particles to deplete the condensable vapour. It was clearly higher during daytime polluted formation events than during clean air events. The rare morning and night time medium high $\mathrm{SO}_{2}$ events do not seem polluted from the point of view of pre-existing aerosol population. Easterly or southerly trajectories during pollution

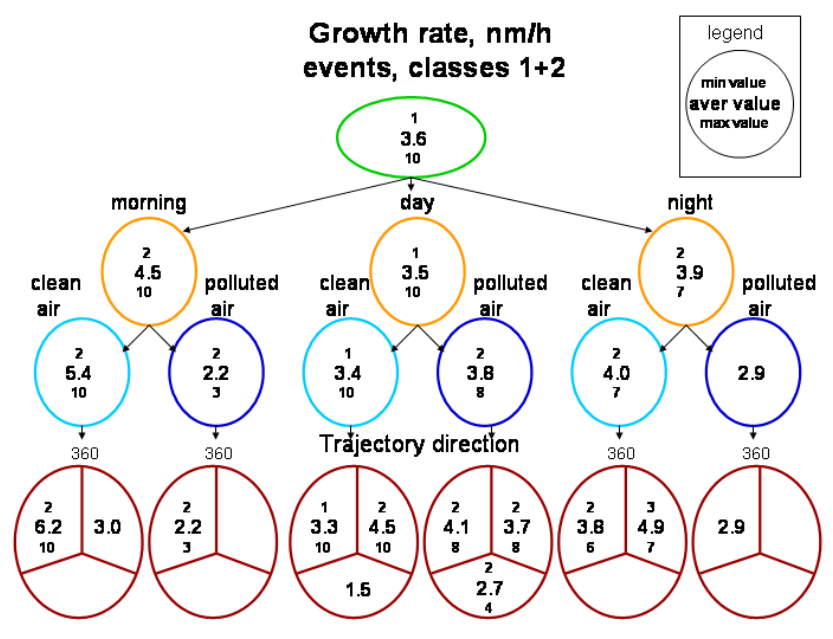

Fig. 10. Average, minimum and maximum growth rates in $\mathrm{nm} / \mathrm{h}$ during class 1 and 2 events, which occurred at different times of the day and in different air masses. Figure 3 shows the number of events falling into the different classes. Note that there were only a few morning and night time events, especially polluted ones, and the statistical significance of the numbers in these classes in limited.

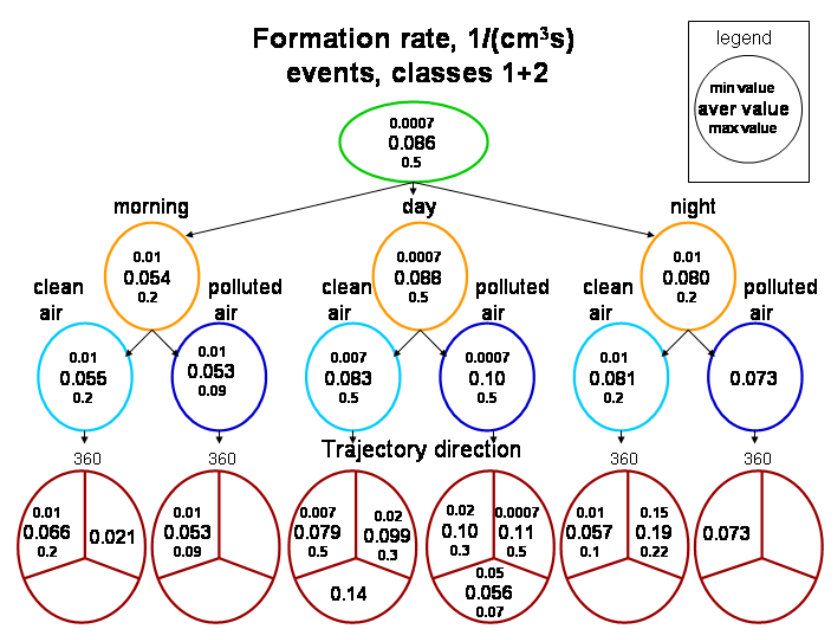

Fig. 11. Average, minimum and maximum formation rates in $1 /\left(\mathrm{cm}^{3} \mathrm{~s}\right)$ during class 1 and 2 events, which occurred at different times of the day and in different air masses. Figure 3 shows the number of events falling into the different classes. Note that there were only a few morning and night time events, especially polluted ones, and the statistical significance of the numbers in these classes is limited.

led to the highest sink values. The condensation sink was, on average, lower on event days compared to the non-event days throughout the year, February being the only exception, possibly due to too few datapoints. The condensation sink clearly decreased before the start of the event in roughly half of the cases. 


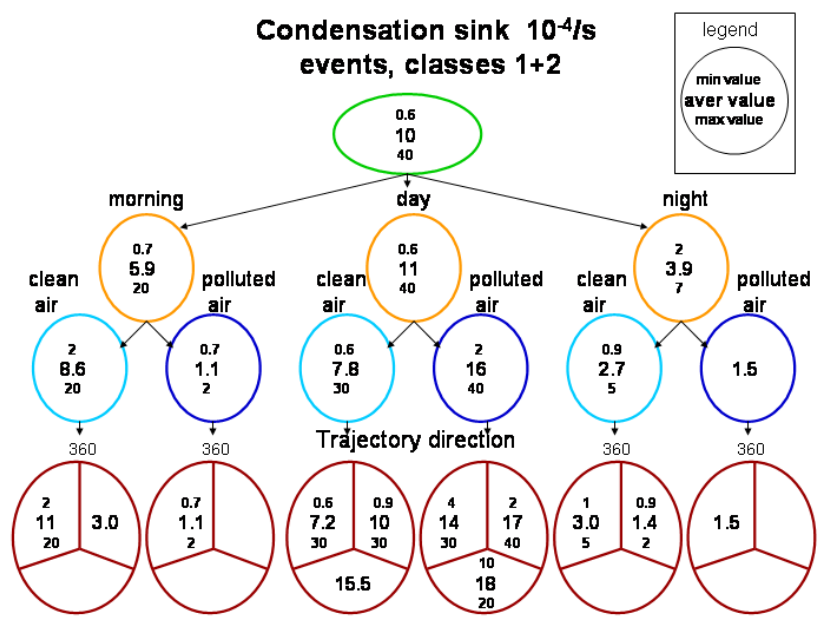

Fig. 12. Average, minimum and maximum condensation sink in $10^{-4} / \mathrm{s}$ calculated from the measured aerosol size distribution during class 1 and 2 events, which occurred at different times of the day and in different air masses. Figure 3 shows the number of events falling into the different classes. Note that there were only a few morning and night time events, especially polluted ones, and the statistical significance of the numbers in these classes is limited.

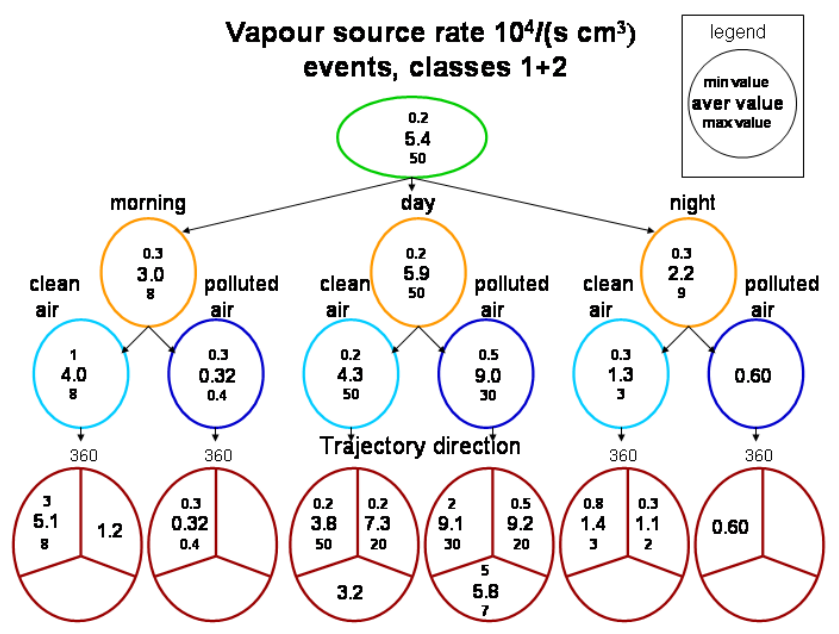

Fig. 13. Average, minimum and maximum vapour source rates in $10^{4} /\left(\mathrm{s} \mathrm{cm}^{3}\right)$ during class 1 and 2 events, which occurred at different times of the day and in different air masses. Figure 3 shows the number of events falling into the different classes. Note that there were only a few morning and night time events, especially polluted ones, and the statistical significance of the numbers in these classes is limited.

Figure 13 shows the condensable vapour source rate in different conditions. The source rate was calculated from the vapour concentration needed to explain the observed growth rate and the condensation sink by assuming that the vapour was in a steady state i.e. the source replaces the losses to aerosol particles (Kulmala et al., 2001). The calculated source rates were high during daytime polluted formation events, since fast vapour production is needed to compensate high condensation sinks and sustain the observed growth. Both for condensation sink and source rate easterly trajectories led to higher values in clean air masses.

\section{Conclusions}

During the calendar years 1998-2002, 147 clear $8 \mathrm{~nm}$ diameter particle formation events have been identified at the SMEAR I station in Värriö, northern Finland. The events have been classified in detail according to the particle formation rate, growth rate, event starting time, different trace gas concentrations and condensable vapour source rates as well as various meteorological conditions. The frequency of particle formation events was highest during the spring months between March and May, suggesting that increasing biological activity might produce the precursor gases necessary for particle formation. Most of the events also occurred during daylight hours, which is usually the case for other observations around the world. However, around twenty events were observed when the sun was below the horizon. Most, but not all, of these events occurred shortly after sunset and could be explained by actual nucleation or initial activation during daylight, but slow growth allowed us to detect the particles only after sunset. There were also a few events during the midwinter polar night. The formation event starting times did not follow the seasonal sunrise variation like they do in SMEAR II Hyytiälä, which also could be due to the larger cut off diameter of the particle sizing instrument in Värriö. In order to study the particle formation rigorously, a measurement system with a $3 \mathrm{~nm}$ cut off diameter (like in Hyytiälä) is also required Värriö.

Our analysis is consistent with earlier studies showing that low relative humidity and low morning temperatures favour particle formation, and high solar radiation and ozone concentrations are typical for formation event days, suggesting the importance of photochemistry. The apparent $8 \mathrm{~nm}$ particle formation rates were around $0.1 / \mathrm{cm}^{3} \mathrm{~s}$, and they were uncorrelated with growth rates, which varied between 0.5 and $10 \mathrm{~nm} / \mathrm{h}$. We have classified the air mass as polluted or nonpolluted on the basis of $\mathrm{SO}_{2}$ concentration using $0.35 \mathrm{ppb}$ as the limit. This classification is crude both due to the arbitrary nature of the limit and due to the fact that $\mathrm{SO}_{2}$ alone is used. The air masses, which had clearly elevated sulphur dioxide concentrations above $1.6 \mathrm{ppb}$ came, as expected, from the direction of the Nikel and Monschegorsk smelters. Only 15 formation events can be explained by the pollution plume from these sources, and none of the dark time events fall into this category. The plumes resulted in higher formation rates of $8 \mathrm{~nm}$ particles compared to clean air formation events, but they did not influence the growth rate of these particles. The condensation sink, which is a measure of the pre-existing particle surface available for condensation correlated with sulphur dioxide concentration, confirming that the $\mathrm{SO}_{2}$ rich air plume was also polluted with particles. 
Acknowledgements. The authors gratefully acknowledge the NOAA Air Resources Laboratory (ARL) for the provision of the HYSPLIT transport and dispersion model and the READY website (http://www.arl.noaa.gov/ready.html) used in this study. This work was supported by the Academy of Finland. We thank the Finnish Environmental Institute for the snow depth data.

Edited by: U. Lohmann

\section{References}

Aalto, P., Hämeri, K., Becker, E., Weber, R., Salm, J., Mäkelä, J. M., Hoell, C., O’Dowd, C. D., Karlsson, H., Hansson, H.-C., Väkevä, M., Koponen, I. K., Buzorius, G., and Kulmala, M.: Physical characterization of aerosol particles during nucleation events, Tellus, 53B, 344-358, 2001.

Birmili, W., Berresheim, H., Plass-Dülmer, C., Elste, T., Gilge, S., Wiedensohler, A., and Uhrner, U.: The Hohenpeissenberg aerosol formation experiment (HAFEX): A long-term study including size-resolved aerosol, $\mathrm{H}_{2} \mathrm{SO}_{4}, \mathrm{OH}$, and monoterpenes measurement, Atmos. Chem. Phys., 3, 361-376, 2003 ,

SRef-ID: 1680-7324/acp/2003-3-361.

Boy, M. and Kulmala, K.: Nucleation events in the continental boundary layer: Influence of physical and meteorological parameters, Atmos. Chem. Phys, 2, 1-16, 2002,

SRef-ID: 1680-7324/acp/2002-2-1.

Dal Maso, M., Kulmala, M., Lehtinen, K. E. J., Mäkelä, J. M., Aalto, P. A., and O'Dowd, C. D.: Condensation and coagulation sinks and formation of nucleation mode particles in coastal and boreal forest boundary layers, J. Geophys. Res., 107, doi:10.1029/2001JD001053, 2002.

Dockery, D. W. and Pope, C. A.: Acute respiratory effects of particulate air pollution, Annu. Rev. Public. Health, 15, 107-132, 1994.

Hari, P., Kulmala, M., Pohja, T., Lahti, T., Siivola, E., Palva, E., Aalto, P., Hämeri, K., Vesala, T., Luoma, S., and Pulliainen, E.: Air pollution in eastern Lapland:challenge for an environmental measurement station, Silva Fennica, 28(1), 29-39, 1994.

Jokinen, V. and Mäkelä, J. M. : Closed loop arrangement with critical orifice for DMA sheath/excess flow system, J. Aerosol Sci., 28, 643-648, 1997.

Kulmala, M.: How Particles Nucleate and Grow, Science, 302, 1000-1001, 2003.

Kulmala, M., Dal Maso, M., Mäkelä, J. M., Pirjola, L., Väkevä, M., Aalto, P., Miikkulainen, P., Hämeri, K., and O'Dowd, C.: On the formation, growth and composition of nucleation mode particles, Tellus B, 53, 479-490, 2001.

Kulmala, M., Pirjola, L., and Mäkelä, J. M.: Stable sulphate clusters as a source of new atmospheric particles, Nature, 404, 66-69, 2000 .
Kulmala, M., Vehkamäki, H., Petäjä, T., Dal Maso, M., Lauri, A., Kerminen, V.-M., Birmili, W., and McMurry, P. H.: Formation and growth rates of ultrafine atmospheric particles: a review of observations, J. Aerosol Sci., 35, 143-176, 2004.

Menon, S., Del Genio, A. D., Koch, D., and Tselioudis, G.: GCM simulations of the aerosol indirect effect: Sensitivity to cloud parameterization and aerosol burden, J. Atmos. Sci., 59, 692713, 2002.

Mäkelä, J. M., Aalto, P., Jokinen, V., Pohja, T., Nissinen, A., Palmroth, S., Markkanen, T., Seitsonen, K., Lihavainen, H., and Kulmala, M.: Observations of ultrafine aerosol particle formation and growth in boreal forest, Geophys. Res. Lett., 24, 1219-1222, 1997.

Mäkelä, J. M., Yli-Koivisto, S., Hiltunen, V., Seidl, W., Swietlicki, E., Teinilä, K., Sillanpää, M., Koponen, I. K., Paatero, J., Rosman, K., and Hämeri, K.: Chemical composition of aerosol during particle formation events in boreal forest, Tellus, 53B, 380393, 2001.

Napari, I., Noppel, M., Vehkamäki, H., and Kulmala, M.: An improved model for ternary nucleation of sulfuric acid-ammoniawater, J. Chem. Phys., 116, 4221-4227, 2002.

Nilsson, E. D., Paatero, J., and Boy, M.: Effects of air masses and synoptic weather on aerosol formation in continental boundary layer Tellus, 53B, 462-478, 2001.

Pirjola, L., Laaksonen, A., Aalto, P., and Kulmala, M.: Sulfate aerosol formation in the Arctic boundary layer, J. Geophys. Res., 103, 8309-8322, 1998.

Ruuskanen, T., Reissell, A., Keronen, P., Aalto, P. P., Laakso, L., Grönholm, T., Hari, P., and Kulmala, M.: Atmospheric trace gas and aerosol particle concentration measurements in Eastern Lapland, Finland 1992-2001, Boreal Env. Res., 8, 335-349, 2003.

Seinfeld, J. H. and Pandis, S. N.: Atmospheric Chemistry and Physics: From Air Pollution to Climate Change, New York, Wiley, 1998.

Shi, Q.: Continuos measurements of $3 \mathrm{~nm}$ to $\mu \mathrm{m}$ aerosol size distributions in St. Louis., Minneapolis MN 55455, 2003.

Stieb, D. M., Judek, S., and Burnett, R. T.: Meta-analysis of timeseries studies of air pollution and mortality: Effects of gases and particles and their influence of cause of death, age and seson, J. Air Manag. Tech., 14, 48-65, 2002.

Stott, P. A., Tett, S. F. B., Jones, G. S., Allen, M. R., Mitchell, J. F. B., and Jenkins, G. J.: External control of 20th century temperature by natural and anthropogenic forcings, Science, 290, 21332137, 2000.

Wiedensohler, A., Hansson, H. C., Orsini, D., Wendish, M., Wagner, F., Bower, K. N., Chourlarton, T. W., Wells, M., Parkin, M., Acker, K., Wieprecht, W., Facchini, M. C., Lind, J. A., Fuzzi, S., Arends, B. G., and Kulmala, M.: Night-time formation and occurrence of new particles associated with orographic cloud, Atmos. Environ., 31, 2545-2559, 1997.

Yu, F. and Turco, R. P.: Ultrafine aerosol formation via ionmediated nucleation, Geophys. Res. Lett., 27, 883-886, 2000. 